\title{
Detection of enterovirus specific RNA sequences in muscle biopsy specimens from patients with adult onset myositis
}

\author{
G E Yousef, D A Isenberg, J F Mowbray
}

\begin{abstract}
A subgenomic cDNA probe with broad specificity for a range of enteroviruses was used to test by an in situ hybridisation technique for the presence of enterovirus specific genomic sequences in muscle biopsy samples obtained from patients with chronic adult myositis. Virus specific RNA sequences were detected in $6 / 13(46 \%)$ patients with idiopathic polymyositis or dermatomyositis. Control samples obtained from an equal number of patients suffering from other muscle disorders were negative. A monoclonal antibody specific for an enterovirus group was used to probe for viral antigens by indirect immunoperoxidase staining; all biopsy samples from test and control groups were negative.
\end{abstract}

Polymyositis is an inflammatory disease of the skeletal muscle characterised by symmetrical weakness of the musculature of the limb girdles, neck, shoulders, and back. ${ }^{1}$ The disease commonly involves the muscles of the diaphragm, chest wall, and pharynx. ${ }^{2}$

Histological features include perivascular mononuclear cell infiltrate, necrosis and phagocytosis of both fibre types, and perivascular atrophy. $^{3}$ The cause is unknown, and the mechanisms responsible for the muscle damage continue to offer fertile ground for scientific investigation.

On the basis of its histopathology and clinical associations polymyositis has been classified within the autoimmune diseases; a view recently emphasised by the finding of large numbers of T lymphocytes, probably bearing the HLA-DR antigen, in the inflammatory infiltrate of muscle of those patients. ${ }^{4}$ The nature of the antigens expressed on the surface of muscle cells which elicit the immune reaction is unknown.

The lack of knowledge of the cause and pathogenesis of polymyositis is reflected occasionally in the confusion of the clinical diagnosis of the condition, especially when it coexists with another autoimmune disease. Bohan and Peter, however, presented a widely accepted classification ${ }^{5}$ of the condition, which they later applied in the study of 153 patients. ${ }^{6}$

There is substantial evidence that cell mediated immunity plays a major part in the pathogenesis of the disease. ${ }^{7}$ In a study of over 200 patients Dawkins and Mastaglia reported a correlation between the activity of myositis and the cytotoxicity of the patients' lymphocytes. ${ }^{8}$

The development of myositis was one of the first features of enterovirus infections to be noted. ${ }^{9}$ Investigation of the role of these viruses in the pathogenesis of human polymyositis dates back to 1959 when Sussman et al isolated Coxsackie B2 virus from the muscle of a one year old child who died of diffuse myositis. ${ }^{10}$ Subsequently, there have been further reports of enteroviral-like particles found by electron microscopy in biopsy specimens of patients with myopathy ${ }^{11-13}$ as well as enteroviral isolation from the muscle homogenates of patients with the disease. ${ }^{214}$ As these findings were obtained from single cases they did not constitute sufficient evidence for a causal relation between enteroviruses and human polymyositis. Furthermore, doubts have been cast upon the true nature of the 'virus-like' particles. Retrospective serology, however, has helped to strengthen the association as a serial rise in serum neutralising antibody titres to group B Coxsackie viruses was found in several patients who developed polymyositis. 1516

An important advance was claimed by Bowles et al when they detected Coxsackie B virus sequences by a slot-blot hybridisation technique in four out of seven muscle biopsy specimens from patients with juvenile dermatomyositis and one out of two patients with polymyositis. ${ }^{17}$ In 10 biopsy specimens from patients with Duchenne muscular dystrophy and in control samples no signals were obtained. Because they used a cDNA probe complementary to the $3^{\prime}$ terminus of Coxsackie B2 virus, which is highly conserved among enteroviruses, ${ }^{18}$ in effect they detected enterovirus specific RNA sequences in addition to the Coxsackie $B$ virus RNA that they indicated. The technique used does not make it possible to identify in an area of diseased muscle which cells are infected with the virus. It is thus difficult to correlate virus infection with the accompanying histopathological changes.

\section{Subjects and methods}

SUBJECTS

The muscle biopsy specimens of 13 adult patients with myositis were studied. Two patients had dermatomyositis, one in association with an underlying carcinoma of the lung. The remaining patients had idiopathic polymyositis. Each of these patients met three or four of the criteria of myositis suggested by Bohan and Peter. ${ }^{5}$ As controls, muscle biopsy specimens from another 13 patients were studied. Six of these patients had muscular dystrophy (four with limb-girdle dystrophy, one facioscapulohumeral, and one Becker), four patients had myalgia of uncertain origin, one patient had a hypothyroid myopathy, one had the hyper- 
eosinophilic syndrome, and one was being investigated for left sided weakness later thought to be due to an encephalitis.

\section{INDIRECT IMMUNOPEROXIDASE}

The coded tissue samples were fixed in buffered formalin $(10 \%$ formalin in phosphate buffered saline (PBS) at pH 7.4), embedded in paraffin, and processed by established procedures. ${ }^{19}$

The tissue sections were deparaffinised by three changes of xylol and rehydrated with graded ethanol (74\% and 64\%) and put in distilled water. They were placed in a Coplin jar containing $0.1 \%$ trypsin (Sigma) and $0.1 \%$ calcium chloride in distilled water with the $\mathrm{pH}$ of the solution adjusted to 7.8 and incubated for 30 minutes at $37^{\circ} \mathrm{C}$. The sections were thoroughly washed in PBS and digested tissue was encircled with a wax pencil to confine reagents and serum samples. Thereafter, the technique of Hyderman ${ }^{20}$ was performed with some modifications as follows: (a) endogenous peroxidase was inhibited with $2 \cdot 28 \mathrm{mM}$ periodic acid in distilled water for five minutes and washed off with tap water; (b) aldehyde groups were blocked with $0.002 \%$ potassium borohydride in distilled water for two minutes and washed off with PBS ( $\mathrm{pH} 7 \cdot 2$ ) containing $0.02 \%$ sodium azide; (c) sections were incubated in a moist chamber at room temperature with first antibody (mouse ascitic fluid of 5-D8/1 antibody which is an enterovirus group reactive monoclone ${ }^{21}$ ) diluted $1: 50$ in 1\% ovalbumin in PBS for 30 minutes; ( $d$ and e) sections were then agitated in PBS bath for 15 minutes, incubated with normal rabbit serum diluted 1:10, to block Fc receptors, for 15 minutes, and washed off with PBS; ( $f$ ) sections were then incubated at room temperature with horseradish peroxidase labelled rabbit antimouse gammaglobulin diluted 1:100 in PBS for 30 minutes and washed off with PBS; (g) sections were incubated in diaminobenzidine, $5 \mathrm{mg}$ freshly dissolved in $10 \mathrm{ml} 0.03 \% \mathrm{H}_{2} \mathrm{O}_{2}$ in $\mathrm{PBS}$, and washed with tap water after 5 minutes or as soon as brown pigments appeared, whichever was first. Slides were counterstained with haematoxylin, and mounted in DPX (Distrene plasticiser xylene; $\mathrm{BDH}$ ).

\section{MOLECULAR HYBRIDISATION \\ Origin of $c D N A$ probes}

The genome of Coxsackie B3 virus (Nancy strain) has been molecularly cloned, and six partially overlapping clones (pCB111 51, 29, 50, $33,35,210)$ containing $7 \cdot 20 \mathrm{kbp}$ of specific Coxsackie virus B3 (CBV3) cDNA were isolated and characterised from a small library of recombinants. ${ }^{22}$ We have previously reported the broad specificity of the pCB111 51 cDNA probe, which contains a fragment that represent the highly conserved $5^{\prime}$ terminal 526 base sequence in the untranslated region of the genome. ${ }^{23}$ vector control ( $\mathrm{pBR} 322)$ were labelled with biotin-11-dUTP (Gibco-BRL) by nick translation using the technique described by Rigby $e t$ $a l .{ }^{24}$ Biotin-11-dUTP was used in place of dTTP in the reaction mixture. The biotin labelled probes were separated from non-incorporated nucleotides by exclusion chromatography on Sephadex G50 (Pharmacia) by the spun column procedure described by Maniatis et $a .^{25}$

\section{In situ hybridisation}

Paraffin sections dewaxed in xylene were rehydrated in graded ethanol and distilled water. Preparations were digested with proteinase $\mathrm{K}$ $(10 \mathrm{mg} / \mathrm{ml})$ for 10 minutes at $37^{\circ} \mathrm{C}$. Endogenous peroxidase activity was reduced by treatment with $3 \%$ hydrogen peroxide solution for five minutes.

Hybridisation mixtures were prepared from $20 \mu$ l biotin labelled probe (400 $\mathrm{ng}$ ), $24 \mu \mathrm{l}$ $20 \times \operatorname{SSC}(0.15 \mathrm{M} \mathrm{NaCl}+0.015 \mathrm{M}$ sodium citrate), $50 \mu \mathrm{l}$ deionised formamide, $10 \mu \mathrm{l}$ denatured sonicated salmon sperm DNA solution (Sigma, $0.8 \mathrm{mg} / \mathrm{ml}$ ), and $16 \mu \mathrm{l}$ distilled water. The DNA probe was denatured by heating this mixture at $100^{\circ} \mathrm{C}$ for 10 minutes and cooling rapidly on ice immediately before use. Aliquots $(5 \mu \mathrm{l})$ of each hybridisation mixture were applied to tissue sections. After sealing the edges of coverslips with Cow Gum rubber solution (Cow Proofings Ltd) the slides were incubated at $42^{\circ} \mathrm{C}$ overnight. Coverslips were removed and the slides washed for 20 minutes in $2 \times$ SSC at room temperature, followed by two 10 minute washes at $65^{\circ} \mathrm{C}$, firstly in $0 \cdot 2 \times$ SSC and then in $0.1 \times$ SSC. Slides were then washed twice in $\mathrm{PBS}$ at room temperature for 10 minutes, rinsing in $0 \cdot 1 \%$ Triton X-100 in between. The slides were drained and incubated with a 1:200 dilution of streptavidin-biotinhorseradish peroxidase (Enzo-Uniscience) at $37^{\circ} \mathrm{C}$ for 60 minutes. The slides were washed again in $0.1 \%$ Triton X-100 in PBS for 15 minutes and the cDNA-RNA hybrids visualised by adding $0.05 \%$ diaminobenzidine in PBS containing $0.03 \%$ hydrogen peroxide. Slides were counterstained with haematoxylin or Evan's blue and dehydrated before mounting in DPX (BDH).

\section{Results}

IMMUNOHISTOCHEMICAL STAINING

Various dilutions of 5-D8/1 monoclone were used as the first antibody but the indirect immunoperoxidase technique did not produce specific brown staining in any of the biopsy specimens from the patients with polymyositis. This indicated that there were no viral specific antigens detectable within the sections. Nevertheless, the peroxidase staining, counterstained with haematoxylin, allowed observation of the histopathological picture. In 9/13 patients there was severe inflammatory muscle disease, characterised by necrosis of muscle fibres, regenerating fibres evident by the presence of fibroblasts and mononuclear cell infiltrate (fig 1 ). In the remaining four patients there were low 


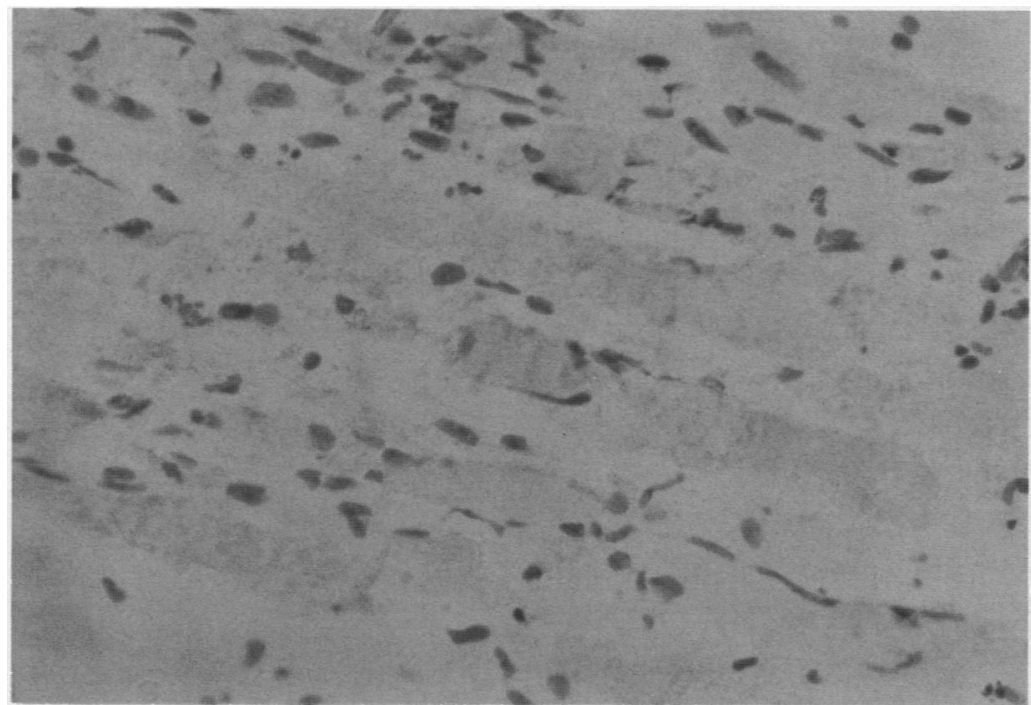

Figure 1: Formalin fixed and paraffin embedded human skeletal muscle tissue from a patient with chronic polymyositis, stained with 5-D8/1 antibody by immunoperoxidase. The section is negative for viral antigens and shows severe necrosis and moderate inflammatory cell infiltration. (Haematoxylin and eosin.)

grade inflammatory changes, with a few small foci of inflammatory cells (fig 2) scattered around the sectioned material. All control samples were negative by $5-\mathrm{D} 8 / 1$ antibody staining, and the histological picture did not conform with that of polymyositis in any of them.

\section{MOLECULAR HYBRIDISATION}

Sections $(5 \mu \mathrm{m})$ prepared from paraffin embedded samples were hybridised in situ with either biotinylated recombinant plasmid pCB111 51 or the pBR322 vector control. Prominent brown signals were seen in muscle biopsy specimens from $6 / 13(46 \%)$ patients with polymyositis. The brown stain was confined to the muscle fibres and did not affect the interstitial space. In four of the patients showing positive hybridisation the muscle inflammation was severe, and signals were seen as clusters within areas of severe inflammatory lesions and muscle necrosis (fig 3). The remaining two patients showing

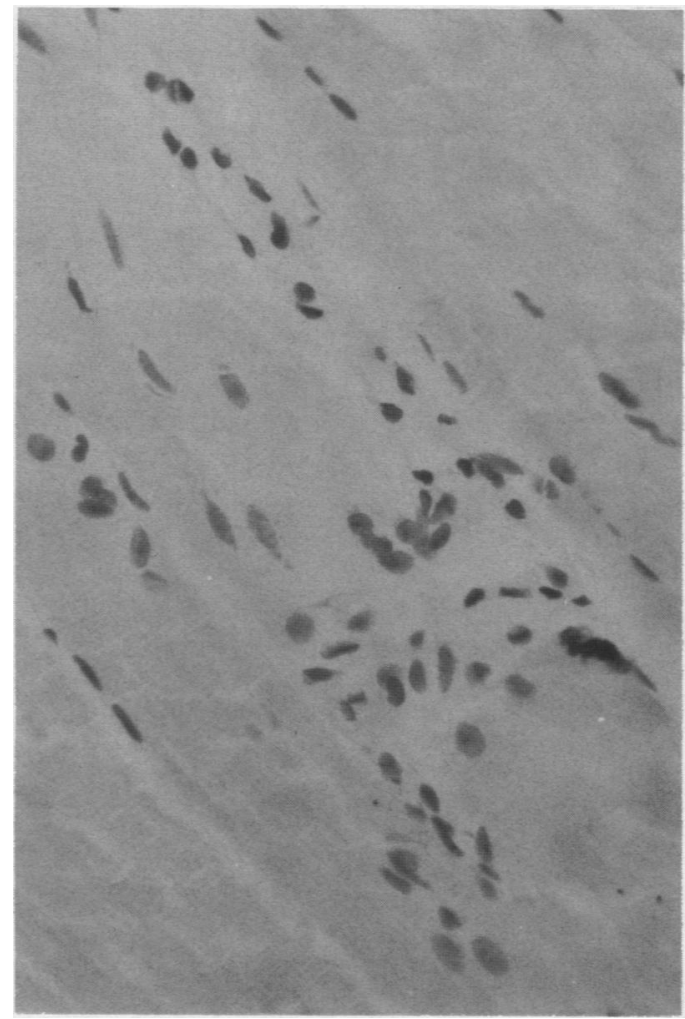

Figure 2: Formalin fixed and paraffin embedded human skeletal muscle tissue from a patient with chronic polymyositis, stained with 5-D8/1 antibody by immunoperoxidase. The section is negative for viral antigens and shows low grade inflammation. (Haematoxylin and eosin.)

positive hybridisation had low grade myositis. In one of them signals were seen in myofibres which showed no necrosis, but there were a few scattered lymphocytes (fig 4). The other patient displayed signals where there was a focus of chronic inflammatory reaction around necrotic myofibres (fig 5). Hybridisation was negative when the specific probes were replaced by biotinylated vector control in adjacent sections (figs 3B, 4B, and 5B). Similarly, none of the biopsy samples obtained from controls showed specific hybridisation.
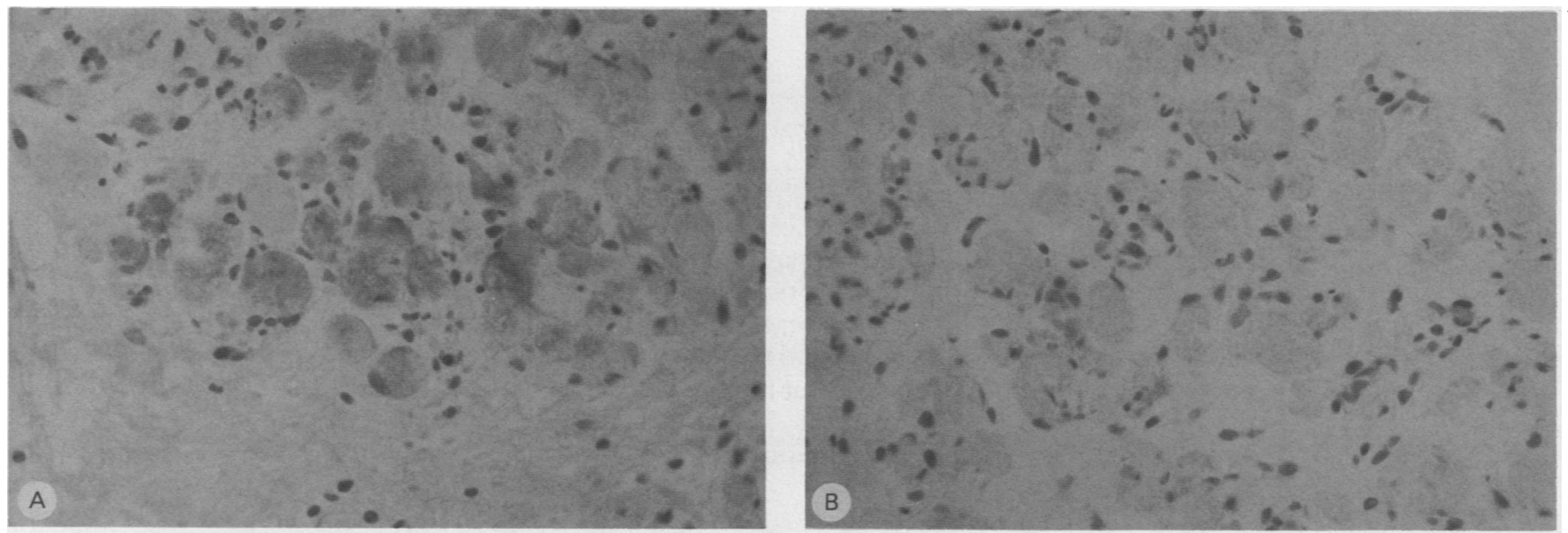

Figure 3: (A) Photomicrograph of sections of skeletal muscle tissues from a patient with severe polymyositis, hybridised in situ with biotin labelled pCB111 51 probe; the brown staining reflects the presence of enterovirus specific genomic sequences. (B) Adjacent sections from the same tissues, but the specific probe was replaced by biotin labelled vector control pBR322. (Counterstained in haematoxylin.) 

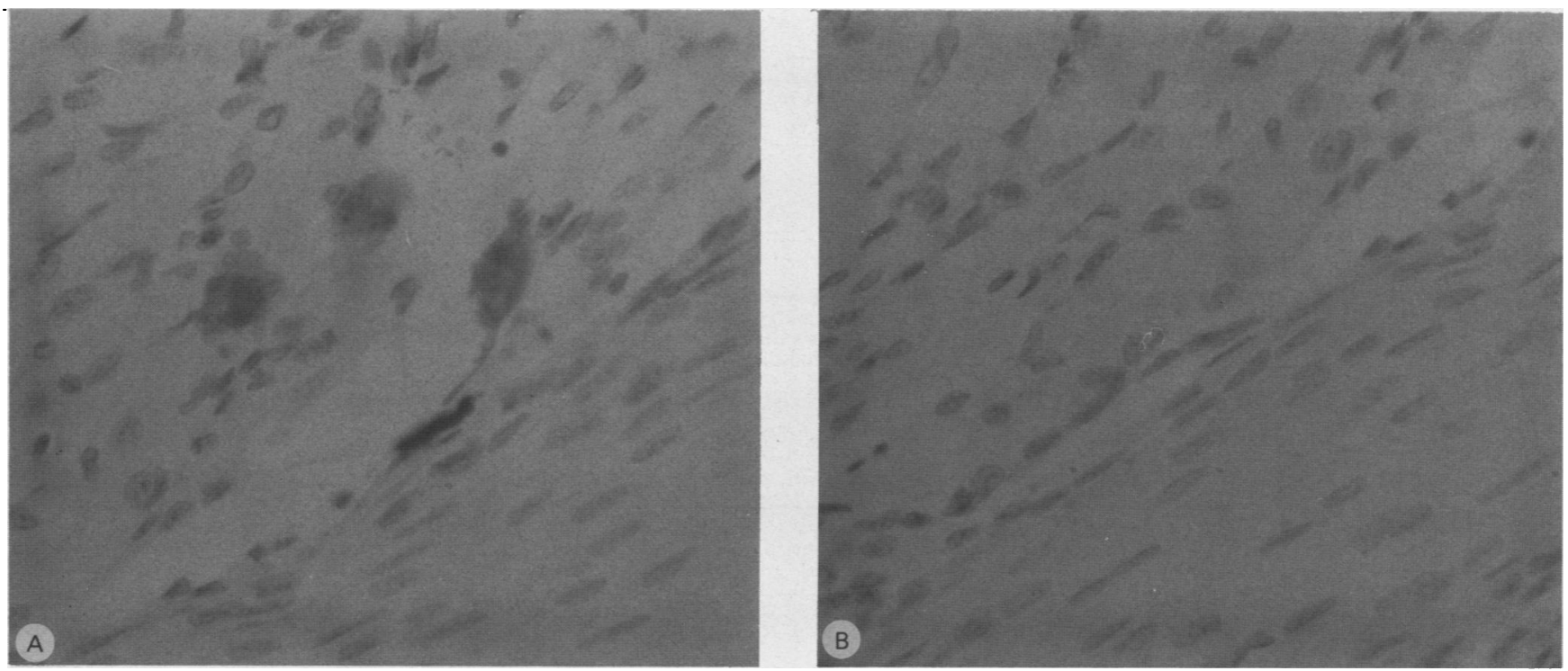

Figure 4: (A) A section from a patient with low grade myositis, hybridised with enterovirus specific $p(B 11151$ probe. Hybridisation signals are seen in areas where there is no necrosis, but there are few scattered lymphocytes. (B) Adjacent section hybridised with the vector control. (Counterstained in haematoxylin.)
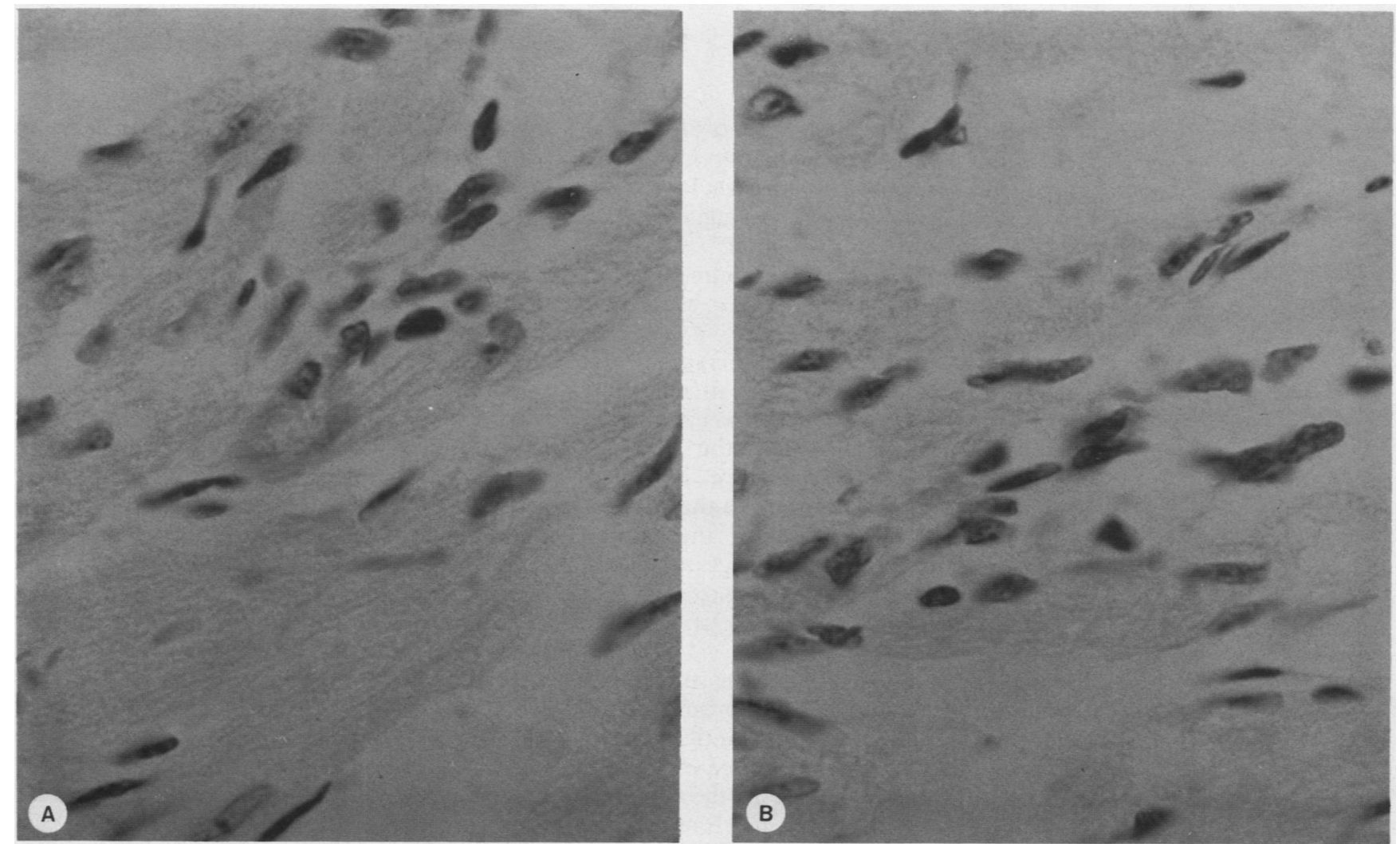

Figure 5: (A)A muscle section from the second patient with low grade myositis, showing posttve hybridisation where there is focus of chronic inflammatory reaction. (B) A section from the same patient hybridised with the vector control (Counterstained in haematoxylin.)

Tables 1 and 2 summarise the essential diagnostic data.

Electromyographic studies were performed and an abnormal electromyogram was seen in $10 / 12$ patients examined. Serum creatine phosphokinase, another index of active myositis, was raised in 11/13 patients (tables 1 and 2).

Analysis of the patients with myositis showing positive hybridisation (table 1) showed that none of them was receiving treatment at the time of the biopsy, whereas three of seven showing negative hybridisation (table 2) were receiving 6-25 $\mathrm{mg}$ of prednisolone a day. Although this might be thought to imply that the negative group had a longer mean duration of symptoms, in fact the mean of 1.3 years (SD 2.0) in this group was a little shorter than the mean for the positive group $(1 \cdot 7(1 \cdot 3))$, but the difference was not statistically significant. In addition, there were no significant differences between the groups for sex, age, abnormal electromyographic findings, creatine phosphokinase levels, or histological findings. Both patients with dermatomyositis were in the negative group. 
Table 1: Clinical data for the patients with polymyositis whose biopsy specimens had enterovirus RNA

\begin{tabular}{llllllll}
\hline $\begin{array}{l}\text { Patient } \\
\text { No }\end{array}$ & Sex & $\begin{array}{l}\text { Age } \\
\text { (years) }\end{array}$ & $\begin{array}{l}\text { Duration } \\
\text { of history } \\
\text { (months) }\end{array}$ & EMG & $\begin{array}{l}\text { CPK } \\
\text { (IU/l) }\end{array}$ & $\begin{array}{l}\text { Biopsy } \\
\text { findings }\end{array}$ & $\begin{array}{l}\text { Current } \\
\text { treatment }\end{array}$ \\
\hline 1 & $\mathrm{~F}$ & 61 & 36 & $+^{*}$ & $100(\mathrm{~N}<70)$ & $\mathrm{A}^{*}$ & None \\
2 & $\mathrm{~F}$ & 50 & 18 & $\mathrm{~N}^{*}$ & $306(\mathrm{~N}<70)$ & $\mathrm{A}$ & None \\
3 & $\mathrm{M}$ & 42 & 6 & + & $93(\mathrm{~N}<235)$ & $\mathrm{B}^{*}$ & None \\
4 & $\mathrm{M}$ & 77 & 12 & + & $411(\mathrm{~N}<70)$ & $\mathrm{A}$ & None \\
5 & $\mathrm{~F}$ & 76 & 48 & + & $\mathbf{N}(\mathrm{N}<70)$ & $\mathrm{A}$ & None \\
6 & $\mathrm{~F}$ & 41 & 3 & $\mathrm{~N}$ & $177000(\mathrm{~N}<190)$ & $\mathrm{B}$ & None
\end{tabular}

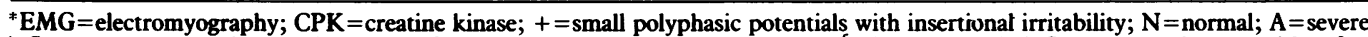
inflammatory myopathy meeting all the features described by Bohan and Peters $; B=$ Tow grade inflammatory changes with a few small foci of inflammatory cells scattered around the sections.

Table 2: Clinical data for the patients with polymyositis whose biopsy specimens did not have enterovirus RNA

\begin{tabular}{|c|c|c|c|c|c|c|c|}
\hline $\begin{array}{l}\text { Patient } \\
\text { No }\end{array}$ & Sex & $\begin{array}{l}\text { Age } \\
\text { (years) }\end{array}$ & $\begin{array}{l}\text { Duration } \\
\text { of history } \\
\text { (months) }\end{array}$ & $E M G^{*}$ & $\begin{array}{l}C P K^{*} \\
(I U / l)\end{array}$ & $\begin{array}{l}\text { Biopsy } \\
\text { findings }\end{array}$ & $\begin{array}{l}\text { Current } \\
\text { treatment }\end{array}$ \\
\hline $\begin{array}{r}7 \\
8 \\
9 \\
10 \\
11 \\
12 \\
13\end{array}$ & $\begin{array}{l}M \\
F \\
F \\
M \\
F \\
F \\
M\end{array}$ & $\begin{array}{l}59 \\
37 \\
31 \\
41 \\
40 \\
79 \\
61\end{array}$ & $\begin{array}{r}12 \\
4 \\
4 \\
6 \\
6 \\
72 \\
6\end{array}$ & $\begin{array}{l}+* \\
+ \\
+ \\
+ \\
\text { Not done } \\
+ \\
+\end{array}$ & $\begin{array}{r}438(\mathbf{N}<195) \\
4345(\mathbf{N}<170) \\
144(\mathbf{N}<122) \\
534(\mathbf{N}<170) \\
301(\mathbf{N}<170) \\
32(\mathbf{N}<70) \\
1117(\mathbf{N}<45)\end{array}$ & $\begin{array}{l}\text { A }^{*} \\
\text { A } \\
\text { A } \\
\text { B }^{*} \\
\text { B } \\
\text { A } \\
\text { A }\end{array}$ & $\begin{array}{l}\text { None } \\
\text { None } \\
\text { None } \\
10 \mathrm{mg} \text { prednisolone } \\
\text { None } \\
6 \mathrm{mg} \text { prednisolone } \\
25 \mathrm{mg} \text { prednisolone }\end{array}$ \\
\hline
\end{tabular}

${ }^{*}$ For abbreviations see table 1 .

\section{Discussion}

The predominantly lymphocytic nature of the cellular infiltrate in muscle biopsy specimens from patients with polymyositis has long been taken as circumstantial evidence suggesting an underlying immune perpetuation. ${ }^{1}$ Although chronic polymyositis shares a common background with many other diseases associated with autoimmunity-for example, it is commoner in women, there is an increased prevalence of HLA-DR3, and the patients often respond to corticosteroids ${ }^{26}$ - the precise trigger mechanisms and reasons why the immune attack persists for so long have remained obscure. It has long been suspected that viruses may be responsible at least for the trigger mechanism. There are several case reports supporting the notion of a pathogenic role for enteroviruses in human chronic polymyositis. ${ }^{2}$ 10-16

Despite the serological evidence supporting enteroviruses as a cause of chronic cardiac and skeletal muscle disease, ${ }^{15}{ }^{16}$ viral antigens have rarely been detected on the surface of muscle cells after the acute phase of the disease. Experimental work on animal models of chronic myocarditis and chronic polymyositis provides further support for this observation. ${ }^{27}{ }^{28}$ Thus it was hardly surprising that the group-specific enteroviral antigen was not detected by immunoperoxidase staining in the muscle biopsy specimens of the patients with polymyositis examined in this study.

The techniques so far used to investigate specimens from patients with suspected viral polymyositis include electron microscopy, virus isolation procedures, and immunohistochemistry. In the study of enteroviruses as a cause of myositis these techniques are limited by various problems: $(a)$ with an electron microscope enteroviruses are difficult to identify if the virus does not form crystalline lattice work and remains in a scattered, free form. In such circumstances the virus may be indistinguishable from ribosomes or glycogen ${ }^{2} ;(b)$ virus isolation procedures are successful only in the acute phase of the disease ${ }^{29} ;(c)$ immunohistochemistry with serotype specific antibodies is not feasible, as is enterovirus serology, because of the high number of distinct enteroviral serotypes that might be implicated in the disease.

Bowles et al have reported the detection of enterovirus specific RNA sequences in biopsy samples obtained from four out of seven patients with juvenile dermatomyositis and one of two patients with adult polymyositis. ${ }^{17}$ They used the slot-blot hybridisation technique, in which total RNA was extracted from the muscle biopsy specimens and hybridised with the radiolabelled cDNA probe. In our study a larger group of patients with chronic adult myositis was investigated by in situ hybridisation with a biotin labelled cDNA probe. This technique, as stated earlier, detects the genomic sequences while preserving the morphology of the sample, providing a means for studying the relation between the infecting virus and the observed disease. Identification of specific cells involved in the infectious process was then made possible by localisation of the viral RNA.

Six of 13 patients with adult onset myositis were shown to have enterovirus infection, while none of the control group was positive. Because of the chronic nature of the illness and the localisation of the hybridisation signals in the affected muscle fibres (fig 3 ) it is reasonable to assume that the infection might have persisted for a long time. The demonstration of viral RNA in the absence of detectable viral antigen might be explained by one or more of the following: $(a)$ the persisting virus is complete, but its capsid proteins are masked by the patient's antibody response, thus rendering it unavailable to react with the probing antibody; (b) persisting infection is low grade and expression of viral antigens is depressed; or $(c)$ the 
virus is persisting in a non-infectious, defective form, which is still capable of perpetuating an immunopathological response.

Earlier reviews have described the different mechanisms by which viruses can induce chronic autoimmune disorders. ${ }^{30} 31$ These fall into four categories: viral infection may cause cell damage, exposing normally hidden antigens against which there is no self tolerance; polyclonal activation of B cells, which may result in expansion of preexisting clones that react with self; molecular mimicry between viral and host proteins; and viral induced new host cell antigens. Evidence for autoimmune muscle disease associated with enterovirus infection has been reported. ${ }^{31} 32$ The results presented here suggest that autoimmunity had been started in these patients, and probably maintained by a low grade persistent enteroviral infection que to reduction of genomic expression. Depressed gene expression may explain the negative results obtained for antigen detection in the muscle biopsy specimens of these patients, but more significantly it explains why the virus was able to evade the host immune system and establish persistent infection.

We thank Dr John Morgan Hughes and Dr Joan Round for supplying us with the biopsy specimens studied. Marjorie Ellison and Bill Russel kindly prepared most of muscle sections for us. The recombinant was a gift from Dr S Tracy.

1 Hudgson P, Walton J. Polymyositis and other inflammatory myopathy. In: Vinken P, Bruyn G W, eds. Handbook of
clinical neurology. Amsterdam: North Holland, 1980: 51-93.

2 Tang J T, Sedmak G V, Siegesmund K A, McCreadie S R. Chronic myopathy associated with coxsackievirus type A9. $A$ combined electron microscopical and viral isolation study. N Engl F Med 1975; 292: 608-11.

3 Isenberg D A, Rowe D, Shearer M, Novick D, Beverley P C L. Localisation of interferons and interleukin 2 in polymyositis and muscular dystrophy. Clin Exp Immunol 1986; 63: $450-8$.

4 Rowe D J, Isenberg D A, McDougall J, Beverley P C L. Characterisation of polymyositis infiltrates using monoclonal antibodies to human leucocyte antigens. Clin Exp Immunol 1981; 45: 290-8.

5 Bohan A, Peter J. Polymyositis and dermatomyositis. N Engl J Med 1975; 292: 344-7.

6 Bohan A, Peter J, Bowman B, Pearson C. A computer assisted analysis of 153 patients with polymyositis and dermatomyositis. Medicine (Baltimore) 1977; 56: 255-86.

7 Cambridge G. Aetiology and pathogenesis of inflammatory muscle disease. Clin Exp Rheumatol 1984; 2: 263-9.

8 Dawkins R L, Mastaglia F L. Cell mediated cytotoxicity to muscle in polymyositis. $N$ Engl f Med 1973; 288: 434-8.
9 Dalldorf G. Neuropathogenicity of group A coxsackie viruses. f Exp Med 1957; 106: 69-76.

10 Sussman M L, Strauss L, Hodes H L. Fatal coxsackie group B virus infection in the newborn. Am $\mathcal{F}$ Dis Child 1959; 97: 483-5.

11 Mastaglia F L, Walton J N. Coxsackievirus-like particles in skeletal muscle from a case of polymyositis. $\mathcal{F}$ Neurol $S c i$ 1970; 11: 593-9.

12 Benn-Bassat M, Machtey I. Picornavirus-like structures in acute dermatomyositis. Am $\mathcal{f}$ Clin Pathol 1972; 58: 245-9.

13 Chou S M, Gutmann L. Picornavirus-like crystals in subacute polymyositis. Neurology 1970; 20: 205-13.

14 Schiraldi O, Iandolo E. Polymyositis accompanying coxsackievirus B2 infection. Infection 1978; 6: 32-4.

15 Travers R L, Hughes G R V, Cambridge G, Sewell J R. Coxsackie $B$ neutralisation titres in polymyositis dermatomyositis. Lancet 1977; i: 1268.

16 Christensen M L, Pachman L M, Schneiderman R, Patel D C, Friedman J M. Prevalence of Coxsackie B virus antibodies in patients with juvenile dermatomyositis. Arthritis Rheum 1986; 29: 1365-70.

17 Bowles N E, Dubowitz V, Sewry C A, Archard L C. Dermatomyositis, polymyositis, and Coxsackie $\mathrm{B}$ virus infections. Lancet 1987; i: 1004-7.

18 Kitamura N, Semler B L, Rothberg P G, et al. Primary structure, gene organisation, and polypeptide expression of structure, gene organisation, and polypeptide
poliovirus RNA. Nature 1981; 291: 547-53.

19 Culling C F A. Handbook of histopathological techniques. 2nd ed. London: Butterworth, 1963: 179-83.

20 Hyderman E. Immunoperoxidase technique in histopathology: applications, methods, and controls. $f$ Clin Pathol 1979; 32: 971-8.

21 Yousef G E, Brown I N, Mowbray J F. Derivation and biochemical characterisation of enterovirus group-reactive monoclonal antibodies. Intervirology 1987; 28: 163-70.

22 Tracy S. A comparison of genomic homologies among the Coxsackie B group: use of fragments of the cloned Coxsackie B3 genome as probes. 7 Gen Virol 1984; 65: 2167-72.

23 Zhang H Y, Yousef G E, Bowles N, Archard L C, Mann G F, Mowbray J F. Detection of Coxsackievirus RNA in myocardium and muscle from infected experimental mice myocardium and muscle from infected experimental mice probes in quantitative slot blots and in situ hybridisation. $\mathcal{J}$ Med Virol 1988; 26: 357-86.

24 Rigby P W, Dieckmann M, Rhodes C, Berg P. Labelling deoxyribonucleic acid to high specific activity in vitro by nick translation with DNA polymerase 1. F Mol Biol 1977; 113: 237-51.

25 Maniatis T, Fritsch E F, Sambrook J. Molecular cloning, a laboratory manual. Cold Spring Harbor, New York: Cold Spring Harbor Laboratory, 1982.

26 Morrow W J, Isenberg D A. Autoimmune rheumatic disease. Morrow W J, Isenberg D A. Autoimmune rhe

27 Wilson F M, Miranda Q R, Chason J L, Lerner A M. Residual pathologic changes following murine coxsackie A and B myocarditis. Am F Pathol 1969; 55: 253-65.

28 Strongwater S L, Dorovini-Zis K, Ball R D, Schnitzer T J. A murine model of polymyositis induced by coxsackievirus Bl (Tucson strain). Arthritis Rheum 1984; 27: 433-43.

29 Melnick J L. Portraits of viruses: the picornaviruses. Intervirology 1983; 20: 61-100.

30 Mims C A, White D O. Persistent infections. In: Mims C, White D, eds. Viral pathogenesis and immunology. Oxford: Blackwell Scientific, 1984: 200-99.

31 Notkins A L, Onodera T, Prabhakar B S. Virus-induced autoimmunity. In: Notkins A L, Oldstone M B A, eds. Concepts in viral pathogenesis. New York: Springer, 1984: $210-5$.

32 Huber S A, Lodge P A. Coxsackievirus B-3 myocarditis in $\mathrm{Balb} / \mathrm{c}$ mice: evidence for autoimmunity to myocyte antigens. Am f Pathol 1984; 116: 21-9. 